\title{
Chemical Compounds and Pharmacological Activities of Mangosteen (Garcinia mangostana L.) - Updated Review
}

\author{
Defri Rizaldy ${ }^{1(\mathbb{D})}$, Rika Hartati ${ }^{2}$ (D) , Trishna Nadhifa ${ }^{1, *} \mathbb{D}^{\mathbb{D}}$, Irda Fidrianny ${ }^{1(\mathbb{D})}$ \\ 1 Department of Pharmaceutical Biology, School of Pharmacy, Bandung Institute of Technology, Bandung, Indonesia; \\ defri.rizaldy@gmail.com (D.R.); rika@fa.itb.ac.id (R.H.); trishnadhifa@gmail.com (T.N.); irdafidrianny@gmail.com \\ (I.F.); \\ * Correspondence: trishnadhifa@gmail.com (T.N.);
}

Received: 22.03.2021; Revised: 30.04.2021; Accepted: 6.05.2021; Published: 18.06.2021

\begin{abstract}
Mangosteen (Garcinia mangostana L.) is a tropical fruit belonging to Guttiferae (syn. Clusiaceae) family. Research on mangosteen has been widely conducted. Also, numerous in vitro and in vivo studies related to mangosteen have been published, indicating its significance and potential usefulness in the research field. This review was constructed by collecting and analyzing more than 50 research articles to explore the phytochemical contents and the medicinal benefits of mangosteen. A significant level of xanthones greatly contributes to the extensive pharmacological activities of mangosteen. Apart from xanthones, mangosteen also contained benzophenones, flavonoids, and anthocyanins. Mangosteen had a wide range of pharmacological effects, including antioxidant, antiacne, anti-aging, anti-hyperpigmentation, antibacterial, antidiabetic, anti-obesity, anti-inflammatory, antimalarial, antiparasitic, and antitumor. Additionally, mangosteen has shown an advantageous activity toward pathological conditions such as Alzheimer's, bipolar disorder, schizophrenia, neuropathic pain, and pulmonary fibrosis. This literature review indicated that xanthone in mangosteen had potential and promising to be developed as a drug candidate. More extensive explorations, especially in pharmacokinetic, pharmacodynamic, and xanthone targeting effects, are widely open to be carried out for future research.
\end{abstract}

Keywords: mangosteen; chemical compounds; pharmacological activities.

(C) 2021 by the authors. This article is an open-access article distributed under the terms and conditions of the Creative Commons Attribution (CC BY) license (https://creativecommons.org/licenses/by/4.0/).

\section{Introduction}

Mangosteen (Garcinia mangostana L.) is one of the most common tropical fruits found in Southeast Asia. It is mainly cultivated in Thailand, Indonesia, Malaysia, Sri Lanka, the Philippines, Myanmar, and India. The Garcinia genus contains about 35 genera and up to 800 species worldwide [1]. Mangosteen hulls have been used in folk medicines to treat gastrointestinal disorders such as abdominal pain, diarrhea and dysentery; cystitis; skin disorders such as psoriasis and eczema; healing of a wound, suppuration and chronic ulcers [2]. Dietary supplements of mangosteen extract have been marketed in the United States lately. Extensive in vivo and in vitro studies on mangosteen pericarp were reported in recent years demonstrated broad pharmacological activities including antioxidant, anticancer, antinociceptive, anti-inflammatory, neuroprotective, anti-obesity, anti-hyperglycemic [3]. Xanthones are the most abundant and the main bioactive component from mangosteen. Publications related to mangosteen have been raised annually, and novel xanthones have been discovered each year. This review article aims to define an update in the chemical compounds and pharmacological activities corresponding to the latest research articles. 


\section{Materials and Methods}

This literature review was performed by collecting and analyzing research articles related to the phytochemical content and the pharmacological effects of mangosteen. All articles were published in PubMed and compiled based on multiple keywords such as 'Mangosteen, G. mangostana, phytochemicals of mangosteen, xanthones, antioxidants, antidiabetic, antimalarial, anti-acne, anticancer, Azlheimer, anti-aging, anti-obesity, antibacterial of mangosteen ". The analysis in this review was elaborated by a minimum of 50 articles published in the last 10 years, including 20 articles in the last 2 years, and the articles must have Digital Object Identifier (DOI).

\section{Chemical Compounds}

Numerous phytochemical screenings on mangosteen pericarps revealed the existence of polyphenolic compounds such as xanthones, benzophenones, flavonoids, and anthocyanins. Xanthones were the main compound present in the mangosteen. Furthermore, mangosteen also contained many nutrients [4]. The nutritional composition of the mangosteen fruit is shown in Table 1. The chemical structure of several phytochemical molecules isolated from $G$. mangostana is described in Figure 1.

Tabel 1. The nutritional composition of the mangosteen fruit.

\begin{tabular}{l|c} 
Nutrient (units) & Value per $\mathbf{1 0 0} \mathbf{g}$ \\
\hline Proximates & 80,94 \\
\hline Water $(\mathrm{g})$ & 0,41 \\
\hline Protein $(\mathrm{g})$ & 0,58 \\
\hline Total lipid $(\mathrm{g})$ & 17,94 \\
\hline Carbohydrate $(\mathrm{g})$ & \\
\hline Minerals & 12,00 \\
\hline Calcium, Ca $(\mathrm{mg})$ & 13,00 \\
\hline Magnesium, Mg (mg) & 48,00 \\
\hline Potassium, K (mg) & A few \\
\hline Other minerals & \\
\hline Vitamins & 2,90 \\
\hline Vitamin C (mg) & 35,00 \\
\hline Vitamin A (IU) & A few
\end{tabular}

\subsection{Polyphenolic compound.}

Mangosteen peels contained 10 times more phenolic compounds and 20 times more antioxidant activity compared to mangosteen pulp. Extraction of the mangosteen pericarp by organic solvent led to the isolations of nonpolar compounds such as xanthones and prenylated benzophenone derivatives. The polar fraction harbor some polar compounds of polyphenols and condensed tannins such as catechins, procyanidins, and anthocyanidins [5].

\subsubsection{Xanthones.}

Xanthones are the major bioactive component found in mangosteen. At least over 68 xanthones derivatives isolated from mangosteen fruit were reported [1,3]. Some xanthones of mangosteen included $\alpha$-mangostin, $\beta$-mangostin, $\gamma$-mangostin, gartanine, 8 -deoxygartanine, mangostinone, 11 $\alpha$-mangostin, mangostanol, 1-isomangostin, 3-isomangostin, and garcinone E. The most abundant xanthones in mangosteen pericarp and bark are $\alpha$ - and $\gamma$-mangostin [6]. $\alpha$-mangostin is the major xanthones derivatives isolated from mangosteen and have been drawn 
attention in the medicinal plant research area due to its extensive biological and pharmacological activities.<smiles>O=c1c2ccccc2oc2ccccc12</smiles>

1) Xanthone<smiles>COc1cc2oc3cc(O)c(C=CC(C)C)c(O)c3c(=O)c2c(O)c1CC=C(C)C</smiles>

2) $\alpha$-mangostin<smiles>COc1cc(O)c2c(=O)c3c(CC=C(C)C)c(CC=C(C)C)c(O)cc3oc2c1</smiles>

3) $\beta$-mangostin<smiles></smiles>

4) $\gamma$-mangostin

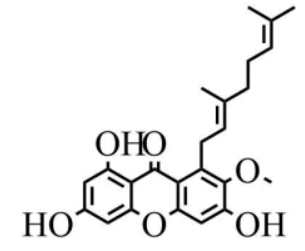

5) Rubraxanthone

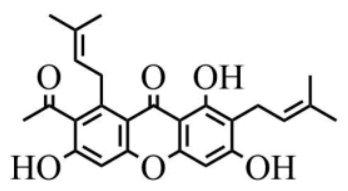

9) Garcixanthone A<smiles>CC(C)=CCc1c(O)c(CC=C(C)C)c2oc3c(O)cccc3c(=O)c2c1O</smiles>

13) 8-Deoxygartanin

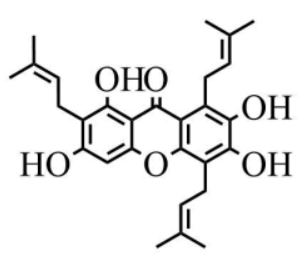

17) Garcinone $E$

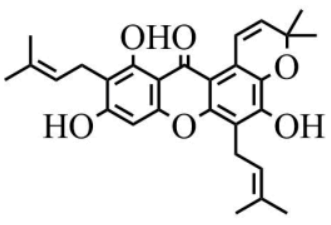

21) Tovophyllin $A$<smiles>COc1cc2oc3cc(O)c(OC)c(CC=C(C)C)c3c(=O)c2c2c1C(C)(O)CCC2(C)O</smiles>

25) Mangostanaxanthone III<smiles></smiles>

6) 9-hydroxycalabaxanthone

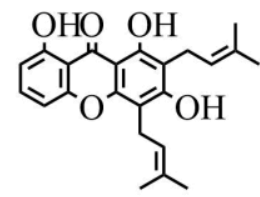

10) Garcixanthone $B$

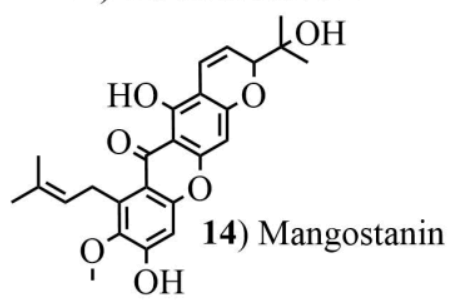<smiles>O=c1c2cc(O)ccc2oc2cccc(O)c12</smiles>

7) Euxanthone<smiles>CC(C)=CCc1c(O)c(C(=O)CC(C)(C)O)c2oc3c(O)ccc(O)c3c(=O)c2c1O</smiles>

11) Garcixanthone $C$

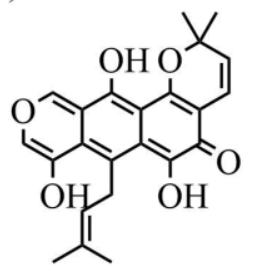

15) Garcinone B<smiles>O=c1c2ccc(O)c(O)c2oc2cc(O)cc(O)c12</smiles>

8) $1,3,5,6-$

Tetrahydroxyxanthone<smiles>CC(C)=CCc1c(O)c(CC=C(C)C)c2oc3c(O)ccc(O)c3c(=O)c2c1O</smiles>

12) Gartanin<smiles>CC(C)=CCc1c(O)c(O)c2c(=O)c3c(CCC(C)(C)O)c(O)c(O)c(O)c3oc2c1O</smiles>

16) Garcinone $C$

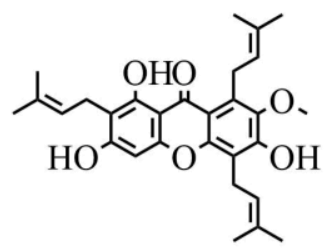<smiles>CC(C)=CCCc1c2c(c(O)c3c(=O)c4cccc(O)c4oc13)C=CC(C)(C)O2</smiles><smiles>CC1(C)C=Cc2c(cc3oc4cc(O)c5c(c4c(=O)c3c2O)C=CC(C)(C)O5)O1</smiles>

20) Padiaxanthone

19) Trapezifolixanthone<smiles>CC(C)=CCCC(C)=CCc1c(O)cc2oc3c(O)cccc3c(=O)c2c1O</smiles>

22) Mangostinone<smiles>COc1c(O)cc2oc3cc(O)c(/C=C\C(C)(C)O)c(O)c3c(=O)c2c1CC=C(C)C</smiles>

26) Mangostanaxanthonoe IV<smiles>CC(C)=CCc1c(O)c(O)cc2oc3cc4c(c(O)c3c(=O)c12)C=CC(C)(C)O4</smiles>

23) 7-O-Dimethyl mangostanin<smiles>CC(C)=CCc1c2c(O)cocc2c(O)c2c3c(c(=O)c(O)c12)CCC(C)(C)O3</smiles>

27) Mangostanaxanthone VII 


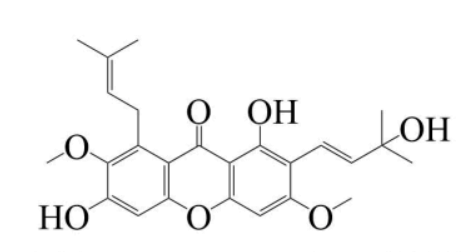

28) Mangostanaxanthone VIII<smiles>CC(O)CCC1C(O)CC2OC3C(C)C(O)C(O)C(O)C3C(O)C2C1O</smiles><smiles>CC(C)=CCC1C(O)C(O)C(O)C2C(O)C3C(CC(O)C(O)C3CCC(C)C)OC12</smiles>

29) Mangostanaxanthone $V$<smiles>CC(C)=CCC1C(O)C(O)CC2OC3CC(CO)C(CCC(C)C)C(O)C3C(=O)C21</smiles>

31) Normangostin<smiles>CC(C)=CCC1=C(O)C2C(=O)c3cccc(O)c3OC2C(CC(O)C(C)C)=C1O</smiles>

33) Garcimangosxanthone I<smiles>CC(C)CCCC(C)CCC1C(O)CC2OC3C(O)CCC(O)C3C2(O)C1O</smiles>

32) Smeaxanthone A<smiles>C=C(C)C(O)CC1C(O)CC2OC3CC(O)C(OC)C(CCC(C)C)C3C(O)C2C1O</smiles>

30) Mangostenol<smiles>COc1cc2c(c(OC)c1CCC(C)(O)O)C(=O)C1C(O)C(CCC(C)C)C(O)CC1C2O</smiles>

32) Mangaxanthone $B$<smiles>O=C(c1ccccc1)c1c(O)cc(O)cc1OC1OC(CO)C(O)C(O)C1O</smiles>

1A) Garcimangosone $D$<smiles>CC(O)CCC1C(O)C(O)C2OC3CC4OC(C)(C)CCC4C(O)C3C(=O)C12</smiles>

34) Garcimangosxanthone $H$<smiles>CC(C)=CCCC(C)CCC1C(O)=C(O)C2OC3C(O)C=CC(O)C3C(O)C2C1O</smiles>

35) Garcimangostin $A$<smiles>O=C(c1ccc(O)c(O)c1)c1c(O)cc(O)cc1OC1OC(CO)C(O)C(O)C1O</smiles>

2A) Rhodanthenone B<smiles>O=C(c1ccc(O)c(O)c1)c1c(O)cc(O)cc1O</smiles>

3A) Maclurin<smiles>OC1CC(O)C2CC(O)C3CC(O)C(O)CC3OC2C1</smiles>

1B) Epicatechin

Figure 1. The molecular structure of some phytochemical compounds isolated from G. mangostana, especially xanthones and its derivatives (1-35), new xanthones (33-35) found between 2019-2020, benzophenones (1A3A), and flavonoid (1B).

In another study, ethanolic extract of mangosteen peels resulted in isolation of 14 xanthone derivatives included 7-O-demethyl mangostanin (1), mangostanin (2), 8deoxygartanin (3), gartanin (4), garcinone E (5), trapezifolixanthone (6), padiaxanthone (7), tovophyllin A (8), 1,5,8-trihydroxy-3-methoxy-2 [3-methyl-2-butenyl]xanthone (9), garcinone B (10), 1,3,7-trihydroxy-2,8-di-(3-methylbut-2-enyl)xanthone (11), mangostenone D (12), mangostinone (13), and 1,7-dihydroxy-2-(3-methylbut-2-enyl)-3-methoxyxanthone (14) [7].

\subsubsection{Benzophenones.}

The major benzophenones in mangosteen fruits have been identified as garcimangosone D, kolanon, and maclurin [8]. In another study, four benzophenones (rhodanthenone B; 
garcimangosone $\quad \mathrm{D} ; \quad$ 3,4,5,3'-tetrahydroxybenzophenone; 4,6,3',4'-tetrahydroxy-2methoxybenzophenone) have been extracted from mangosteen peels using hot water as the minor constituent in isolate [5].

\subsubsection{Anthocyanins.}

Anthocyanins components in mangosteen fruits have been elucidated as cyanidin-3-Oglucoside, cyanidin- -3-O-sophoroside, and chrysanthemum [8].

3.1.4. Other phenolic compounds.

NMR proton of hot water extract from mangosteen peels revealed epicatechin (flavonoid) along with procyanidin B2 (epicatechin dimer) as the main polyphenolic components in the isolate [5].

\section{Pharmacological Activities}

\subsection{Anti-acne.}

Multiherb extracts (G. mangostana, Lithospermum officinale, Tribulus terrestris L., Houttuynia cordata Thunb) in cleanser formulation were tested on 60 patients with mild to moderate acne for 8 weeks. Acne lesion counts were performed and resulted in a significant reduction in inflammatory and non-inflammatory acne. The average reduction in inflammatory acne was $56 \%$ compared to day 0 and non-inflammatory acne was reduced by $36 \%$ [9].

Another study was conducted on 77 patients with mild to moderate acne. Patients were randomly distributed into groups then given a topical herbal extract formula (tea tree oil, mangosteen pericarp, niacinamide $4 \%$ ) or $2.5 \%$ Benzoyl Peroxide for 12 weeks. The analysis of the lesion showed a significant reduction in acne. These antimicrobial and anti-inflammatory activities against $C$. acnes are due to terpinen-4-o and xanthone components in tea tree oil and mangosteen peels [10].

Another clinical study on 28 patients with mild to moderate acne revealed the $0.5 \%$ mangosteen peel extracts (containing 94\% $\alpha$-mangostin based on high-performance liquid chromatography- HPLC) in nanoparticle-loaded gel significantly reduced about $67 \%$ of comedones and inflammatory lesions after 12-week treatment. Alpha-mangostin possessed a strong antimicrobial against $C$. acnes [11].

\subsection{Anti-aging and anti-hyperpigmentation.}

An increase of reactive oxygen species (ROS) was the main cause of oxidative stress lead to skin aging, and the application of antioxidants such as mangosteen pericarp extract (MPE) can delay the occurrence of aging. Skin aging was also associated with decreased skin elasticity and the degradation of hyaluronic acid, which generates hyperpigmentation. MPE showed a strong anti-elastase effect. Elastase of human skin was a process of elastin degradation that led to the loss of skin elasticity. Based on its $\mathrm{IC}_{50}$ value, elastase inhibition activity increased as follow: $\gamma$-mangostin $<$ garcinone $\mathrm{D}<\alpha$-mangostin $<$ garcinone $\mathrm{C}<\mathrm{MPE}$. Gamma-mangostin had the potential as an anti-hyaluronidase that maintained skin moisture and anti-tyrosinase to prevent hyperpigmentation [12]. Other studies have shown that alphamangostin had the potential to reduce skin wrinkles due to ultraviolet B (UV-B) exposure in hairless mouse models with UV-B damage-induced HaCaT cells [13]. 


\subsection{Alzheimer.}

Alpha-mangostin could be a potential candidate for therapy of Alzheimer's disease (AD), considering the beneficial activities of mangosteen such as anti-inflammatory, antioxidant, and neuroprotective [14]. In vitro studies on the rat model suggested that $\alpha$ mangostin with $\mathrm{EC}_{50}$ values of $3.89 \mathrm{Nm}$ inhibits amyloid aggregation via limitation of $\mathrm{A} \beta$ fibril formation [15].

\subsection{Bipolar disorder, schizophrenia and cholinesterase inhibitor.}

Bipolar disorder and schizophrenia have been comprehended to be related to a substantial increase in oxidative stress levels such as reactive oxygen species (ROS), reactive nitrogen species (RNS), thiobarbituric acidic reactive substances (TBARS) and malondialdehyde (MDA). Mangosteen hulls were found to reduce those four types of oxidative stress levels significantly in a rat model. Thus, the mangosteen hulls appear as possible supplemental therapy for bipolar disorder and schizophrenia [16].

Another study revealed that the methanol extract of mangosteen peels and calyx possessed strong inhibitory activities against acetylcholinesterase (AChE) and butyrylcholinesterase $(\mathrm{BChE})$ with $\mathrm{IC}_{50}$ values of 0.90 and $0.37 \mu \mathrm{g} / \mathrm{ml}$ due to $\alpha$ - and $\gamma$ compounds [17].

In vitro studies demonstrated six xanthones compounds isolated from mangosteen peels extract had cholinesterase inhibitory effects with $\mathrm{IC}_{50}$ value of $1.28-8.0 \mu \mathrm{g} / \mathrm{ml}$ through Ellman's microplate assay. The results showed that one of the xanthone derivatives, Garcinone $\mathrm{C}$ possessed strong inhibitory effects in $\mathrm{AChE}$ with an IC50 value of $1.24 \mu \mathrm{M}$, while $\gamma$-mangostin inhibits BChe with IC50 value of $1.78 \mu \mathrm{M}$. Molecular docking study exposed mangostanol, 3isomangostin, garcinone $\mathrm{C}$ and $\alpha$-mangostin contributed to the AChE inhibitory activities, 8deoxygartanin in $\mathrm{BChE}$ inhibitor, while $\gamma$-mangostin inhibited both $\mathrm{AChE}$ and -BChE [18].

Another study suggested that $\alpha$-mangostin could be a potential adjuvant therapy for schizophrenia and haloperidol due to its antidepressant-like properties, further assisting the anti-immobility responses to these drugs through maternal immune activation (MIA) models [19].

A clinical trial using adjunctive $1000 \mathrm{mg} /$ day of the mangosteen pericarp on 150 schizophrenia patients for 24 weeks was shown in the positive and negative symptom scale and successfully gained ethical and regulatory approval [20].

\subsection{Neuropathic pain.}

The effects of $\alpha$-mangostin on the peripheral neuropathic pain caused by chronic constriction injury (CCI) were evaluated in rats for 14 days. This study suggested that $\alpha$ mangostin ameliorates the progression and the existence of CCI-induced neuropathic pain due to its antioxidant, anti-inflammatory, and anti-apoptotic properties. Antioxidant properties were measured as malondialdehyde (MDA) and glutathione (GSH) level. Anti-inflammatory properties was evaluated by analysis of inflammatory markers (cyclooxygenase-2 (COX2), interleukin 1 beta (IL-1 $\beta$ ), inducible nitric oxide synthase (iNOS), nitric oxide (NO), toll-like receptor 4 (TLR-4), metalloproteinases-2 (MMP2), and tumor necrosis factor-alpha (TNF- $\alpha$ ) level. Anti-apoptotic properties were evaluated by Bcl-2, Bax, and caspase-3 levels. The results showed that $\alpha$-mangostin increased MDA level and decreased GSH level. Both MDA level and 
GSH level were conversely observed in CCI group. Alpha-mangostin $(50 \mathrm{mg} / \mathrm{kg})$ enhanced the levels of all inflammatory markers, Bax, and caspase-3 on the day 7 and 14 [21].

\subsection{Antibiotic growth promotoripolar disorder.}

Mangosteen peel extract (MPE) 2\% was fed to a group of 30 1-day-old broiler chicks for 30 days and showed no increase in the rate of antibiotic resistance, while the colistin-treated group had increases in antibiotic resistance rate. Thus, MPE poses a potential as natural antibiotic growth promoters, which develop the performance of boilers production without elevating the antibiotic resistance rate [22].

\subsection{Antibacterial.}

An in vitro research reported the antibacterial activity of mangosteen pericarp extract against methicillin-resistant Staphylococcus aureus (MRSA) with the minimum inhibitory concentration (MIC) and minimum bactericidal concentration (MBC) 0.02 to $1.25 \mathrm{mg} / \mathrm{ml}$ and 0.03 to $5 \mathrm{mg} / \mathrm{ml}$, while for $\alpha$-mangostin were 1.56 to $12.50 \mu \mathrm{g} / \mathrm{ml}$ and 3.91 to $100 \mu \mathrm{g} / \mathrm{ml}$ [23].

In another study, alpha-mangostin showed antibacterial activity against $S$. pseudintermedius (both methicillin-resistant S. pseudintermedius (MRSP) dan meticillinsusceptible $S$. pseudintermedius (MSSP) ) with the MIC of $\alpha$-mangostin related to MSSP was $0.53 \pm \mu \mathrm{g} / \mathrm{ml}$ and the MIC on MRSP was $0.47 \pm 0.27 \mu \mathrm{g} / \mathrm{ml}$ through in vitro time-kill method [24].

In vitro experiment was carried out to demonstrate inhibitory effects of mangosteen peel extracts (MPE) on $S$. mutants and $P$. gingivalis in biofilm formation (tooth) through crystal violet biofilm assay. The results indicated that MPE significantly inhibited both bacterial during incubation of $6 \mathrm{~h}$, but the effective concentration of MPE was 100\% over an incubation period of $24 \mathrm{~h}$ [25].

Mangosteen peel extracts (MPE) with $5 \mathrm{mg} / \mathrm{ml}$ concentration in natural products biosynthesized silver nanoparticle (Ag-NPs) formula was evaluated against oral infection caused by Listeria monocytogenes in BALB/c female mice. The in vivo experiment reported that MPE enhanced the immunogenicity against L. monocytogenes as demonstrated by the elevated survival time, decreased pathological changes in intestinal tissue, and enhancement of immune response [26].

\subsection{Antidiabetic.}

Garcimangostin A, a new xanthone from the mangosteen pericarp extract, had an $\alpha-$ amylase inhibitory effect with $94.1 \%$ inhibition compared to acarbose (96.7\%). This result showed that mangosteen can decrease the postprandial glucose absorption, thus advantageous for the treatment and/or prevention of diabetes [27]. The in vitro antidiabetic activity of the aqueous extract of mangosteen vinegar rind (MVP) was analyzed in streptozotocin-induced type II diabetes nephropathy mice. The result indicated that MVP induced $\alpha$-amylase inhibitory activities with the IC50 values $422.82 \pm 7.83 \mu \mathrm{g} / \mathrm{ml}$ [28]. Another in vitro study on High Fat Diet/-Streptozotocin or HFD-/STZ-induced DM mice suggested that xanthones ( $\alpha$-mangostin and $\gamma$-mangostin) in the mangosteen pericarp inhibited pancreatic- $\alpha$-amylase with IC $_{50}$ values $409.59 \pm 6.81 \mu \mathrm{g} / \mathrm{ml}[29]$. 


\subsection{Anti-inflammatory and wound healing.}

A topical formulation containing G. mangostana pericarp ethanolic extract (GME) was tested on MRSA-infected tape stripping model mice. The wounds were completely healed on the last day of the experiment (day 10) and the number of MSRA-colonies decreased from the first day of the study. Significant reduction of pro-inflammatory cytokines expression (TNF- $\alpha$, IL-6, and IL-1 $\beta$ ) was exhibited by GME through modulation of TLR-2 pathway by $\alpha-\beta$ - and $\gamma$-mangostin also garcinone B components [23]. Another study revealed that the combination of $1 \mu \mathrm{g} / \mathrm{ml}$ mangosteen and $34 \mu \mathrm{g} / \mathrm{ml}$ propolis extracts were highly effective as antiinflammatory and in vitro bone formation agents [30]. In another study, $1 \mu \mathrm{g} / \mathrm{ml}$ of the mangosteen extract reduced IL-6 and IL-8 (inflammatory cytokines) expression in $5 \mu \mathrm{g} / \mathrm{ml} P$. gingivalis KCOM 2804 LPS-treated hTERT-hNOF cells [31].

\subsection{Antioxidant.}

The fresh and frozen peel (pericarp) and the flesh (pulp) of G. mangostana were extracted by ultrasound-assisted extraction method for 15, 30 and $60 \mathrm{~min}$. Ethanol within $20 \%$, $40 \%, 70 \%$ and $96 \%$ (v/v) concentrations were used as solvent. The antioxidant activity was measured using 2,2-diphenyl-1-picrylhydrazyl (DPPH), 2,2'-azino-bis-(3ethylbenzothiazoline-6-sulfonic acid (ABTS), cupric reducing antioxidant capacity (CUPRAC), ferric reducing antioxidant power (FRAP) and ferrous ion chelating (FIC) methods, whereas the total phenolic content was measured using the Folin-Ciocalteu (F-C) method. The result indicated that a higher antioxidant activity in fresh peel extracts corresponds to several antioxidant compounds. The F-C technique measured the highest polyphenol content from the fresh plant material extract [8]. Pectin was isolated from the mangosteen peel extract and the antioxidant potential was observed by the DPPH method. The result showed a moderate antioxidant activity with the $\mathrm{IC}_{50}$ of about $161.93 \pm 31.57 \mu \mathrm{g} / \mathrm{ml}$ [32].

\subsection{Antitumor.}

In vitro studies on the phytochemicals from mangosteen had been demonstrated to inhibit the cancer cells proliferation and metastasis and exhibited an anti-apoptosis effect in certain human malignancies such as breast [33-35], lung [36], liver [37-40], colon [37], oral [41-43], skin [44], leukemia [45], prostate [46,47] and cervical cancers [43,48].

In breast cancer, mangostanaxanthone VII from the chloroform fraction of mangosteen pericarps extract was able to decrease the breast cancer cells viability towards the A549 and Michigan Cancer Foundation-7 (MCF-7) cancer cell lines through Sulforhodamine B (SRB) assay with the $\mathrm{IC}_{50}$ values 26.1 to $34.8 \mu \mathrm{M}$ [33]. Another xanthone, alpha-mangostin from the mangosteen extract, was tested on the MDA-MB-231 spheroid breast tumor cell lines to demonstrate the anti-proliferative activities. The experiment reported that $\alpha$-mangostin significantly decreased the cell viability in MDA-MB-231 for $48 \mathrm{~h}$ incubating period with doses higher than $\mathrm{IC}_{50}=0.70-1.25 \mu \mathrm{g} / \mathrm{ml}$ ) [34]. Additionally, four phytochemicals compounds ( $\alpha$-mangostin, $\beta$-mangostin, mangaxanthone $\mathrm{B}$, and mangaphenone) were isolated from the stem barks of $G$. mangostana and G. benthamiana (Planch. \& Triana) Pipoly were also reported to promote apoptosis towards MCF-7 and MDA-MB-231 breast cells line through 3-(4,5dimethylthiazol-2-yl)-2,5-diphenyltetrazolium bromide (MTT) assay with the IC50 values in the range of $4.4-12.0 \mu \mathrm{M}$ via estrogen receptor (ER) and fatty acid synthase (FAS) signaling pathways [35]. 
In the lung cancer, alpha-mangostin showed a considerable anti-proliferative effect on small cell lung cancer [36]. In liver and colon cancer, anticancer activities of garcinone E, 7$\mathrm{O}$-methylgarcinone $\mathrm{E}$ and $\alpha$-mangostin components from mangosteen have been demonstrated in the human hepatocellular, breast, and colorectal cancer cell lines [37]. Alpha-mangostin was shown to possess an anti-proliferative effect on the liver cell line [38].

In oral and cervical cancer, alpha-mangostin was effective against the YD-15 tongue mucoepidermoid carcinoma cells and the squamous cell carcinoma of the oral cavity $[41,42]$. Mangosteen pericarp ethanolic extract (MPE) was tested in the human tongue squamous cell carcinoma (H357) cells and the cervical cancer cells (HeLa) for anticancer activities through the MTT assay, Terminal deoxynucleotidyl transferase (TdT) dUTP Nick-End Labeling (TUNEL) assay, western blotting, and flow cytometry techniques. The results revealed that MPE significantly repressed the growth of H357 and HeLa cells in a dose-dependent manner and early apoptosis was induced by MPE after incubation for $48 \mathrm{~h}$. The results indicated that MPE also increased the expression of pro-apoptotic proteins such as caspases and Bax, and decreased the expression of anti-apoptotic protein Bcl-2. These results proved the cytotoxic and apoptotic effect of MPE on oral and cervical cancer due to its rich constituents, including tannins, flavonoids, proteins, steroids, and cardiac glycosides [43]. The anticancer effect of $\alpha-$ mangostin on the human cervical cancer cell was investigated using in vitro and in vivo studies [48].

In the skin cancer, $\alpha$-mangostin had the ability to inhibit 9, 10dimethylbenz[a]anthracene (DMBA)/TPA-induced skin cancer by reducing the inflammation and inducing autophagy and apoptosis via three key proteins phospho-PI3K (p-PI3K), p-AKT and p-mTOR (PI3K/Akt/mTOR) signaling pathway in mice [44]. In leukemia, $\alpha$-mangostin induced autophagy augments in the chronic myeloid leukemia cell [45].

In prostate cancer, $\alpha$-mangostin also showed an apoptotic activity against $22 \mathrm{Rv} 1$ prostate cancer cells [46]. Mangosteen pericarp powder (MPP) effect was evaluated on prostatic hyperplasia in 24 male F344 rats. This study suggested that MPP application can alleviate the development of prostatic hyperplasia because of its anti-proliferative effect by lowering the serum testosterone level and dihydrotestosterone concentrations, promoting lipid peroxidation, also improving of inflammation and mitochondrial function in the prostate tissues [47].

\subsection{Inflammatory bowel disease.}

Mangosteen extract and $\alpha$-mangostin reduced the degree of ulcerative colitis (UC) induced by dextran sulfate sodium (DSS) in mice. Furthermore, a recent study revealed that this mechanism occurred by suppressing nuclear factor-kappa B (NF-kB) activation due to mangosteen's anti-inflammatory and antioxidant effect $[49,50]$.

\subsection{Antiobesity.}

Administration of $\alpha$-mangostin $(50 \mathrm{mg} / \mathrm{kg}$ ) for 5 weeks in HFD-induced obesity mice have been proved to decrease the hepatic steatosis, accumulation of fat and body weight through the regulation of lipid metabolism via modulation of SIRT1-adenosine monophosphate-activated protein kinase (AMPK) and peroxisome proliferator-activated receptor $\gamma(\operatorname{PPAR} \gamma)$ pathways [51]. 


\subsection{Antimalarial.}

Antimalarial activity of $\alpha$-mangostin was demonstrated by virus titer assay through plaque assay method. Alpha-mangostin was tested against the dengue virus infection (DENV2) in human peripheral blood mononuclear cells (PBMC). Alpha-mangostin could potentially inhibit virus replication due to its higher concentration. The results showed $50 \%$ viral reduction after treatment using 10 and $20 \mu \mathrm{M}$ of $\alpha$-mangostin at 24 - and 48 -h post-infection, in which the $48 \mathrm{~h}$ treated group had a more percentage reduction effect. The $\mathrm{IC}_{50}$ values were 5.47 and 5.77 $\mu \mathrm{M}$ for 24- and 48-h treatments, respectively [52].

Another in vitro study was conducted on the antimalarial activity of $\alpha$-mangostin in DENV infection in hepatocellular carcinoma HepG2 and Huh-7 cell lines. The results demonstrated that $\alpha$-mangostin inhibited both DENV production and cytokine/chemokine expression in HepG2 cells [53].

\subsection{Antiparasitic.}

Alpha-Mangostin was tested on nematode Caenorhabditis elegans. The results revealed that $\alpha$-mangostin caused growth inhibition in C. elegans population with the $\mathrm{LC}_{50}$ value of 3.8 $\pm 0.5 \mu \mathrm{M}$ [54].

\subsection{Pulmonary fibrosis.}

In vivo study indicated that $\alpha$-mangostin treatment $(10 \mathrm{mg} / \mathrm{kg} /$ day $)$ significantly reduced the oxidative stress in bleomycin (BLM)-induced pulmonary fibrosis in mice by initiating AMPK mediated signaling pathway and stimulated primary lung fibroblasts (PLFs) and downregulated the accumulation of extracellular matrix (ECM) [55].

\subsection{Chronic kidney disease (CKD).}

In silico study predicted the protective role of $\alpha-, \beta-, \gamma$-mangostin in PbAc-induced CKD by activating the Nrf-2 and regulating NF-kB and MAPK pathways. The plausible mechanisms correlated to the antioxidant activity of these xanthones [56].

\section{Conclusions}

The mangosteen (G. mangostana L.) contained several chemical compounds, especially xanthones, benzophenones, flavonoids, and anthocyanins. These components were proven to generate beneficial human health conditions through various pharmacological activities such as antioxidant, anti-acne, anti-aging, anti-hyperpigmentation, antibacterial, antidiabetic, antiobesity, anti-inflammatory, antimalarial, antiparasitic, and antitumor. Furthermore, chemical compounds isolated from mangosteen have shown advantageous outcomes for multiple pathological conditions includes Alzheimer's, various cancers, bipolar disorder, schizophrenia, neuropathic pain, CKD, and pulmonary fibrosis. This review indicated that xanthone in mangosteen has the potential to be developed as a promising drug candidate. Further exploration of mangosteen as drug candidates may include pharmacokinetic, pharmacodynamic, and xanthone targeting effects that possible to be carried out in the future study. 


\section{Funding}

This research received no external funding.

\section{Acknowledgments}

This research was supported by the School of Pharmacy, Bandung Insitute of Technology.

\section{Conflicts of Interest}

The authors declare no conflict of interest.

\section{References}

1. Al-Massarani, S.M.; El Gamal, A.A.; Al-Musayeib, N.M.; Mothana, R.A.; Basudan, O.A.; Al-Rehaily, A.J. Phytochemical, antimicrobial and antiprotozoal evaluation of Garcinia Mangostana pericarp and $\alpha$ mangostin, its major xanthone derivative. Molecules 2013, 18, 10599-10608, https://doi.org/10.3390/molecules180910599.

2. Chen, G.; Li, Y.; Wang, W.; Deng, L. Bioactivity and pharmacological properties of $\alpha$-mangostin from the mangosteen fruit: a review. Expert Opin Ther Pat 2018, 28, 415-427, https://doi.org/10.1080/13543776.2018.1455829.

3. Ovalle-Magallanes, B.; Eugenio-Pérez, D.; Pedraza-Chaverri, J. Medicinal properties of mangosteen (Garcinia mangostana L.): A comprehensive update. Food Chem Toxicol 2017, 109, 102-122, https://doi.org/10.1016/j.fct.2017.08.021.

4. Devalaraja, S.; Jain, S.; Yadav, H. Exotic fruits as therapeutic complements for diabetes, obesity and metabolic syndrome. Food Res Int 2011, 44, 1856-1865, https://doi.org/10.1016/j.foodres.2011.04.008.

5. Yoshimura, M.; Ninomiya, K.; Tagashira, Y.; Maejima, K.; Yoshida, T.; Amakura, Y. Polyphenolic constituents of the pericarp of mangosteen (Garcinia mangostana L.). J Agric Food Chem 2015, 63, 76707674, https://doi.org/10.1021/acs.jafc.5b01771.

6. Tousian Shandiz, H.; Razavi, B.M.; Hosseinzadeh, H. Review of Garcinia mangostana and its xanthones in metabolic syndrome and related complications. Phyther Res 2017, 31, 1173-1182, https://doi.org/10.1002/ptr.5862.

7. Yang, R.; Li, P.; Li, N.; Zhang, Q.; Bai, X.; Wang, L.; Xiao, Y.; Sun, L.; Yang, Q.; Yan, J. Xanthones from the pericarp of Garcinia mangostana. Molecules 2017, 22, 1-10, https://doi.org/10.3390/molecules22050683.

8. Muzykiewicz, A.; Zielonka-Brzezicka, J.; Siemak, J.; Klimowicz, A. Antioxidant activity and polyphenol content in extracts from various parts of fresh and frozen mangosteen. Acta Sci Pol Technol Aliment 2020, 19, 261-270, https://doi.org/10.17306/J.AFS.0788.

9. Yang, J.H.; Hwang, E.J.; Moon, J.; Yoon, J.Y.; Kim, J.W.; Choi, S. Clinical efficacy of herbal extracts in treatment of mild to moderate acne vulgaris: an 8-week, double-blinded, randomized, controlled trial. $J$ Dermatolog Treat 2019, https://doi.org/10.1080/09546634.2019.1657792.

10. Lubtikulthum, P.; Kamanamool, N.; Udompataikul, M. A comparative study on the effectiveness of herbal extracts vs $2.5 \%$ benzoyl peroxide in the treatment of mild to moderate acne vulgaris. J Cosmet Dermatol 2019, 18, 1767-1775, https://doi.org/10.1111/jocd.12962.

11. Lueangarun, S.; Sriviriyakul, K.; Tempark, T.; Managit, C.; Sithisarn, P. Clinical efficacy of $0.5 \%$ topical mangosteen extract in nanoparticle loaded gel in treatment of mild-to-moderate acne vulgaris: A 12-week, split-face, double-blinded, randomized, controlled trial. J Cosmet Dermatol 2019, 18, 1395-1403, https://doi.org/10.1111/jocd.12856.

12. Widowati, W.; Ginting, C.N.; Lister, I.N.E. Anti-aging Effects of mangosteen peel extract and its phytochemical compounds : antioxidant activity, enzyme inhibition and molecular docking simulation. Trop Life Sci Res 2020, 31, 127-144, https://doi.org/10.21315/tlsr2020.31.3.9.

13. Im, A.R.; Kim, Y.M.; Chin, Y.W.; Chae, S. Protective effects of compounds from Garcinia mangostana L. (mangosteen) against UVB damage in HaCaT cells and hairless mice. Int J Mol Med 2017, 40, 1941-1949, https://doi.org/10.3892/ijmm.2017.3188.

14. Chen, Y.; Bian, Y.; Wang, J.W.; Gong, T.T.; Ying, Y.M.; Ma, L.F.; Shan, W.-G.; Xie, X.-Q.; Zhan, Z.-J. Effects of $\alpha$-mangostin derivatives on the alzheimer's disease model of rats and their mechanism: a combination of experimental study and computational systems pharmacology analysis. ACS Omega 2020, 5 , 9846-9863, https://doi.org/10.1021/acsomega.0c00057.

15. Wang, Y.; Xia, Z.; Xu, J.R.; Wang, Y.X.; Hou, L.N.; Qiu, Y.; Chen, H.-Z. $\alpha$-Mangostin, a polyphenolic xanthone derivative from mangosteen, attenuates $\beta$-amyloid oligomers-induced neurotoxicity by inhibiting $\begin{array}{lllll}\text { amyloid } & \text { aggregation. } & \text { Neuropharmacol } & \text { 2012, } & \text { 82, }\end{array}$ 
https://doi.org/10.1016/j.neuropharm.2011.09.016.

16. Ashton, M.M.; Dean, O.M.; Walker, A.J.; Bortolasci, C.C.; Ng, C.H.; Hopwood, M.; Harvey, B.H.; Moller, M.; McGrath, J.J.; Marx, W.; Turner, A.; Dodd, S.; Scott, J.G.; Khoo, J.-P.; Walder, K.; Sarris, J.; Berk, M. The therapeutic potential of mangosteen pericarp as an adjunctive therapy for bipolar disorder and schizophrenia. Fron Psychi 2019, 10, 1-17, https://doi.org/10.3389/fpsyt.2019.00115.

17. Khaw, K.Y.; Chong, C.W.; Murugaiyah, V. LC-QTOF-MS analysis of xanthone content in different parts of Garcinia mangostana and its influence on cholinesterase inhibition. J Enzyme Inhib Med Chem 2020, 35, 1433-1441, https://doi.org/10.1080/14756366.2020.1786819.

18. Khaw, K.Y.; Choi, S.B.; Tan, S.C.; Wahab, H.A.; Chan, K.L.; Murugaiyah, V. Prenylated xanthones from mangosteen as promising cholinesterase inhibitors and their molecular docking studies. Phytomedicine 2014, 21, 1303-1309, https://doi.org/10.1016/j.phymed.2014.06.017.

19. Lotter, J.; Möller, M.; Dean, O.; Berk, M.; Harvey, B.H. Studies on Haloperidol and adjunctive $\alpha$-mangostin or raw Garcinia mangostana Linn pericarp on bio-behavioral markers in an immune-inflammatory model of schizophrenia in male rats. Fron Psychi 2020, 11, 1-15, https://doi.org/10.3389/fpsyt.2020.00121.

20. Turner, A.; McGrath, J.J.; Dean, O.M.; Dodd, S.; Baker, A.; Cotton, S.M. Protocol and rationale: A 24-week double-blind, randomized, placebo controlled trial of the efficacy of adjunctive Garcinia mangostana Linn. (Mangosteen) pericarp for schizophrenia. Clin Psychopharmacol Neurosci 2019, 17, 297-307, https://doi.org/10.9758/cpn.2019.17.2.297.

21. Ghasemzadeh, R.M.; Razavi, B.M.; Hosseinzadeh, H. Investigating the ameliorative effect of alphamangostin on development and existing pain in a rat model of neuropathic pain. Phyther Res 2020, 1-15, https://doi.org/10.1002/ptr.6768.

22. Herawati, O.; Untari, T.; Anggita, M.; Artanto, S. Effect of mangosteen (Garcinia mangostana L.) peel extract as an antibiotic growth promoter on growth performance and antibiotic resistance in broilers. Vet Wor 2020, 13, 796-800, https://doi.org/10.14202/vetworld.2020.796-800.

23. Tatiya-aphiradee, N.; Chatuphonprasert, W.; Jarukamjorn, K. Anti-inflammatory effect of Garcinia mangostana Linn. pericarp extract in methicillin-resistant Staphylococcus aureus-induced superficial skin infection in mice. Biomed Pharmacother 2019, 111, 705-713, https://doi.org/10.1016/j.biopha.2018.12.142.

24. Larsuprom, L.; Rungroj, N.; Lekcharoensuk, C.; Pruksakorn, C.; Kongkiatpaiboon, S.; Chen, C.; Sukata, U. In vitro antibacterial activity of mangosteen (Garcinia mangostana Linn.) crude extract against Staphylococcus pseudintermedius isolates from canine pyoderma. Vet Dermatol 2019, 30, 487-545, https://doi.org/10.1111/vde.12783.

25. Widyarman, A.S.; Lay, S.H.; Wendhita, I.P.; Tjakra, E.E.; Murdono, F.I.; Binartha, C.T. Indonesian mangosteen fruit (Garcinia mangostana L.) peel extract inhibits Streptococcus mutans and Porphyromonas gingivalis in Biofilms in vitro. Contemp Clin Dent 2019, 10, 123-128, 10.4103/ccd.ccd_758_18.

26. Alkhuriji, A.F.; Majrashi, N.A.; Alomar, S.; El-Khadragy, M.F.; Awad, M.A.; Khatab, A.R.; Yehia, H.M. The beneficial effect of eco-friendly green nanoparticles using Garcinia mangostana peel extract against pathogenicity of Listeria monocytogenes in female BALB/c mice. Anim 2020, 10, https://doi.org/10.3390/ani10040573.

27. Ibrahim, S.R.M.; Mohamed, G.A.; Khayat, M.T.A.; Ahmed, S.; Abo-Haded, H. $\alpha$-Amylase inhibition of xanthones from Garcinia mangostana pericarps and their possible use for the treatment of diabetes with molecular docking studies. J Food Biochem 2019, 43, 1-9, https://doi.org/10.1111/jfbc.12844.

28. Karim, N.; Rahman, A.; Chanudom, L.; Thongsom, M.; Tangpong, J. Mangosteen vinegar rind from Garcinia mangostana prevents high-fat diet and Streptozotocin-induced type II diabetes nephropathy and apoptosis. $J$ Food Sci 2019, 84, 1208-1215, https://doi.org/10.1111/1750-3841.14511.

29. Karim, N.; Rahman, M.A.; Changlek, S.; Tangpong, J. Short-time administration of xanthone from Garcinia mangostana fruit pericarp attenuates the hepatotoxicity and renotoxicity of type II diabetes mice. J Am Coll Nutr 2020, 39, 501-510. https://doi.org/10.1080/07315724.2019.1696251.

30. Lim, Y.K.; Yoo, S.Y.; Jang, Y.Y.; Lee, B.C.; Lee, D.S.; Kook, J.K. Anti-inflammatory and in vitro bone formation effects of Garcinia mangostana L. and propolis extracts. Food Sci Biotechnol 2020, 29, 539-548, https://doi.org/10.1007/s10068-019-00697-3.

31. Yiemwattana, I.; Kaomongkolgit, R. Alpha-mangostin suppresses IL-6 and IL-8 expression in P. gingivalis LPS-stimulated human gingival fibroblasts. Odontol 2015, 103, 348-355, https://doi.org/10.1007/s10266014-0160-7.

32. Wathoni, N.; Yuan Shan, C.; Yi Shan, W.; Rostinawati, T.; Indradi, R.B.; Pratiwi, R.; Muchtaridi, M. Characterization and antioxidant activity of pectin from Indonesian mangosteen (Garcinia mangostana L.) rind. Heliyon 2019, 5, 2299, https://doi.org/10.1016/j.heliyon.2019.e02299.

33. Ibrahim, S.R.M.; Mohamed, G.A.; Elfaky, M.A.; Zayed, M.F.; El-Kholy, A.A.; Abdelmageed, O.H.; Ross, S.A. Mangostanaxanthone VII, a new cytotoxic xanthone from Garcinia mangostana. Zeitschrift fur Naturforsch - Sect C J Biosci 2018, 73, 185-189, https://doi.org/10.1515/znc-2017-0122.

34. Scolamiero, G.; Pazzini, C.; Bonafè, F.; Guarnieri, C.; Muscari, C. Effects of $\alpha$-mangostin on viability, growth and cohesion of multicellular spheroids derived from human breast cancer cell lines. Int J Med Sci 2018, 15, 23-30, https://doi.org/10.7150/ijms.22002.

35. See, I.; Cheng, G.; Ee, L.; Yi, V.; Jong, M.; Teh, S.S.; Cespedes Acuna, C.L.; Mah, S.H. Cytotoxic activity 
of phytochemicals from Garcinia mangostana L . and $G$. benthamiana ( Planch . \& Triana ) Pipoly against breast cancer cells cytotoxic activity of phytochemicals from Garcinia. Nat Prod Res 2020, 1-6, https://doi.org/10.1080/14786419.2020.1836629.

36. Zhang, C.; Yu, G.; Shen, Y. The naturally occurring xanthone $\alpha$-mangostin induces ROS-mediated cytotoxicity in non-small scale lung cancer cells. Saudi J Biol Sci 2018, 25, 1090-1095, https://doi.org/10.1016/j.sjbs.2017.03.005.

37. Mohamed, G.A.; Al-Abd, A.M.; El-halawany, A.M.; Abdallah, H.M.; Ibrahim, S.R.M. New xanthones and cytotoxic constituents from Garcinia mangostana fruit hulls against human hepatocellular, breast, and colorectal cancer cell lines. J Ethnopharmacol 2017, 198, 302-312, https://doi.org/10.1016/j.jep.2017.01.030.

38. Wudtiwai, B.; Pitchakarn, P.; Banjerdpongchai, R. Alpha-mangostin, an active compound in Garcinia mangostana, abrogates anoikis-resistance in human hepatocellular carcinoma cells. Toxicol Vitr 2018, 53, 222-232, https://doi.org/10.1016/j.tiv.2018.09.003.

39. Fazry, S.; Noordin, M.A.M.; Sanusi, S.; Noor, M.M.; Aizat, W.M.; Lazim, A.M., Dyari, H.R.E.; Jamar, N.H.; Remali, J.; Othman, B.A.; Law, D.; Sidik, N.M.; Cheah, Y.H.; Lim, Y.C. Cytotoxicity and toxicity evaluation of xanthone crude extract on hypoxic human hepatocellular carcinoma and zebrafish (Danio rerio) embryos. Toxics 2018, 6, https://doi.org/10.3390/toxics6040060.

40. Lee, C.W.; Chen, Y.F.; Wu, H.H.; Lee, O.K. Historical perspectives and advances in mesenchymal stem cell research for the treatment of liver diseases. Gastroenterol 2018, 154, 46-56, https://doi.org/10.1053/j.gastro.2017.09.049.

41. Lee, H.N.; Jang, H.Y.; Kim, H.J.; Shin, S.A.; Choo, G.S.; Park, Y.S. Antitumor and apoptosis-inducing effects of $\alpha$-mangostin extracted from the pericarp of the mangosteen fruit (Garcinia mangostana L.) in YD15 tongue mucoepidermoid carcinoma cells. Int J Mol Med 2016, 37, 939-948, https://doi.org/10.3892/ijmm.2016.2517.

42. Fukuda, M.; Sakashita, H.; Hayashi, H.; Shiono, J.; Miyake, G.; Komine, Y.; Taira, F.; Sakashita, H. Synergism between $\alpha$-mangostin and TRAIL induces apoptosis in squamous cell carcinoma of the oral cavity through the mitochondrial pathway. Oncol Rep 2017, 38, 3439-3446, https://doi.org/10.3892/or.2017.6030.

43. Janardhanan, S.; Mahendra, J.; Mahendra, L.; Devarajan, N. Cytotoxic effects of mangosteen pericarp extracts on oral cancer and cervical cancer cells. Asian Pacific J Cancer Prev 2020, 21, 2577-2583, https://doi.org/10.31557/APJCP.2020.21.9.2577.

44. Wang, F.; Ma, H.; Liu, Z.; Huang, W.; Xu, X.; Zhang, X. $\alpha$-Mangostin inhibits DMBA/TPA-induced skin cancer through inhibiting inflammation and promoting autophagy and apoptosis by regulating PI3K/Akt/mTOR signaling pathway in mice. Biomed Pharmacother 2017, 92, 672-680, https://doi.org/10.1016/j.biopha.2017.05.129.

45. Chen, J.J.; Long, Z.J.; Xu, D.F.; Xiao, R.Z.; Liu, L.L.; Xu, Z.F.; Qiu, S.X.; Lin, D.-J.; Liu, Q. Inhibition of autophagy augments the anticancer activity of $\alpha$-mangostin in chronic myeloid leukemia cells. Leuk Lymphoma 2014, 55, 628-638, https://doi.org/10.3109/10428194.2013.802312.

46. Li, G.; Petiwala, S.M.; Nonn, L.; Johnson, J.J. Inhibition of CHOP accentuates the apoptotic effect of $\alpha$ mangostin from the mangosteen fruit (Garcinia mangostana) in 22Rv1 prostate cancer cells. Biochem Biophys Res Commun 2014, 453, 75-80, https://doi.org/10.1016/j.bbrc.2014.09.054.

47. Tsai, H.H.; Chen, C.W.; Yu, P.L.; Lin, Y.L.; Hsieh, R.H. Mangosteen pericarp components alleviate progression of prostatic hyperplasia and mitochondrial dysfunction in rats. Sci Rep 2020, 10, 1-9, https://doi.org/10.1038/s41598-019-56970-2.

48. Pérez-Rojas, J.M.; González-Macías, R.; González-Cortes, J.; Jurado, R.; Pedraza-Chaverri, J.; GarcíaLópez, P. Synergic effect of $\alpha$-mangostin on the cytotoxicity of cisplatin in a cervical cancer model. Oxid Med Cell Longev 2016, 2016, https://doi.org/10.1155/2016/7981397.

49. Chae, H.S.; You, B.H.; Song, J.; Ko, H.W.; Choi, Y.H.; Chin, Y.W. Mangosteen extract prevents dextran

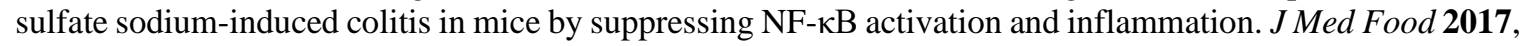
20, 727-733, https://doi.org/10.1089/jmf.2017.3944.

50. Tatiya-aphiradee, N.; Chatuphonprasert, W.; Jarukamjorn, K. Ethanolic Garcinia mangostana extract and $\alpha$ mangostin improve dextran sulfate sodium-induced ulcerative colitis via the suppression of inflammatory and oxidative responses in ICR mice. $J$ Ethnopharmacol 2021, 265, 113384, https://doi.org/10.1016/j.jep.2020.113384.

51. Choi, Y.H.; Bae, J.K.; Chae, H.S.; Kim, Y.M.; Sreymom, Y.; Han, L.; Jang, H.Y.; Chin, Y.-W. $\alpha$-mangostin regulates hepatic steatosis and obesity through SirT1-AMPK and PPAR $\gamma$ pathways in high-fat diet-induced obese mice. J Agric Food Chem 2015, 63, 8399-8406, https://doi.org/10.1021/acs.jafc.5b01637.

52. Sugiyanto, Z.; Yohan, B.; Hadisaputro, S.; Dharmana, E.; Suharti, C.; Winarto; Djamiatun, K.; Rahmi, F.L.; Sasmono, R.T. Inhibitory effect of alpha-mangostin to dengue virus replication and cytokines expression in human peripheral blood mononuclear cells. Nat Products Bioprospect 2019, 9, 345-349, https://doi.org/10.1007/s13659-019-00218-z.

53. Tarasuk, M.; Songprakhon, P.; Chimma, P.; Sratongno, P.; Na-Bangchang, K.; Yenchitsomanus, P.-T. Alphamangostin inhibits both dengue virus production and cytokine/chemokine expression. Virus Res 2017, 240, 180-189, https://doi.org/10.1016/j.virusres.2017.08.011. 
54. Markowicz, J.; Uram, Ł.; Sobich, J.; Mangiardi, L.; Maj, P.; Rode, W. Antitumor and anti-nematode activities of $\alpha$-mangostin. Eur J Pharmacol 2019, 863, 172678, https://doi.org/10.1016/j.ejphar.2019.172678.

55. Li, R.S.; Xu, G.H.; Cao, J.; Liu, B.; Xie, H.F.; Ishii, Y.; Zhang, C. Alpha-mangostin ameliorates bleomycininduced pulmonary fibrosis in mice partly through activating adenosine 5 '-monophosphate-activated protein kinase. Front Pharmacol 2019, 10, 1305, https://doi.org/10.3389/fphar.2019.01305.

56. Rana, M.N.; Tangpong, J.; Rahman, M.A. Xanthones protects lead-induced chronic kidney disease (CKD) via activating Nrf-2 and modulating NF-kB, MAPK pathway. Biochem Biophys Report 2020, 21, 100718, https://doi.org/10.1016/j.bbrep.2019.100718. 